\title{
Diet selection by deer: principles, practice and consequences
}

\author{
G.P. COSGROVE ${ }^{1}$ and J. HODGSON ${ }^{2}$ \\ ${ }^{1}$ AgResearch Grasslands, Private Bag 11008, Palmerston North \\ ${ }^{2}$ Institute of Natural Resources, Private Bag 11222, Massey University, Palmerston North \\ gerald.cosgrove@agresearch.co.nz
}

\begin{abstract}
The role of diet selection by farmed deer in their nutrient intake and species selection, and the consequences for the management of forages, is considered. In common with sheep and cattle, sward surface height ( $\mathrm{SSH}$ ) is the most influential sward physical factor on the ability of deer to meet their daily nutrient demand from grazed pasture, and a $\mathrm{SSH}$ of $10 \mathrm{~cm}$ is required for maximum intake and performance. Deer discriminate among pasture species, generally preferring legumes and herbs to grasses. The grass dominance and low proportion of clover in typical permanent pasture grazed by deer reflects their selection for clover and avoidance of grass. This dominance of grass and the difficulty deer face in selecting for alternative species that are present only in a low proportion may constrain intake even when sward height is not limiting. Summer-growing forage species such as red clover (Trifolium pratense), white clover (Trifolium repens), birdsfoot trefoil (Lotus comiculatus), sulla (Hedysarum coronarium) and chicory (Cichorium intybus) have high nutritive value, and result in high liveweight gains by deer when provided as specialist swards at critical feeding times. Recent studies indicate that ruminants prefer to eat mixed diets, and management systems that enable mixed grass-clover pastures with a high proportion of legume to be sustained under selective grazing by deer would provide high nutritive value and maintain a balance between winter and summer in the seasonal distribution of pasture dry matter production.
\end{abstract}

Keywords: Cervidae, deer, diet selection, forage, grazing behaviour, nutrient intake, preference

\section{Introduction}

Ruminants in general have evolved many complex anatomical and behavioural adaptations, suiting them for utilising a wide range of natural grassland and shrub land resources. They have adjusted readily over comparatively short periods to intensive grazing systems, which in NZ are based on a narrow range of predominantly temperate grasses and legumes. The successful transition of deer to domestication reflects the adaptability of the species and the skill of early entrepreneurs who facilitated such changes.

The high levels of productivity, longevity, and health of intensively farmed animals compared to their feral counterparts indicates that the benefits of intensive pastoral systems far outweigh any detrimental aspects. However, in imposing intensive pasture-based management systems on ruminants, the expression of evolved feeding behaviours may be constrained in ways that are poorly understood. This paper will firstly consider the red deer (for which there is comparatively little information derived under intensive grazed pasture systems) in the context of a broader understanding of other ruminant species, mainly sheep and cattle. Having established the scope and limitations for extrapolation among species, the specific aspects of deer grazing behaviour are considered. Using recent examples, potential constraints to nutrient intake by the management systems imposed are considered along with the opportunities that may arise to improve the nutrition of grazing deer.

The pragmatic view is taken that diet selection is one aspect contributing to an animal's nutrient intake, the purpose being to influence the total nutrient intake or the balance of nutrients eaten, and to regulate or even avoid the intake of negative or antiquality factors. Studies of grazing behaviour, diet selection and preference are at times seen as esoteric, with little direct relevance for the nutrition of farmed animals. Perhaps this can be at least partly explained by the emphasis in New Zealand on maximising per hectare productivity, with high stocking rates and high utilisation of forage favoured, often at the cost of restricted animal productivity. However, we will argue that even where management systems aim for high levels of forage utilisation, diet selection has both shortterm and long-term consequences for animals and for the pastures they graze.

\section{Diet selection and nutrient intake}

Selective grazing may enable an animal to increase the nutrient density of its diet above that in the food supply offered. However, selection also influences the composition of the herbage on offer by removing preferred species and plant parts and leaving the less preferred. In grazed pastures, the balance between removal of plant parts by grazing and replacement by plant growth determines the longer-term effects on pasture, and therefore, diet composition. Where it is a greater priority to achieve high per animal productivity than high per hectare a productivity, the nutrient density of the forage available, and more importantly the scope for deer to increase the nutrient density of their diet 
above that of the forage offered by selection, both affect intake and productivity. It follows that constraints on selection might restrict animal performance.

\section{Morphological attributes of deer that affect selection and nutrient intake}

Ruminants in general have a wide variety of ingestive and digestive strategies, which interact as compensating mechanisms enabling them to exploit a variety of feeding opportunities. The size of individual bites and the rate of biting and chewing, the particular parts of plants and species selected, the time spent grazing and ruminating, are all inter-related. The animal is capable of considerable flexibility in the way it regulates these aspects of grazing and constraints on any one may be compensated by adjustment of others.

The wide range of genera and species of deer, and the wide variation in mature body size makes it difficult to generalise with respect to the allometric relationships among body mass, metabolic rate and requirements, size of mouthparts and digestive capacity, and the implications for feeding behaviour. Red deer (Cervus elaphus L.), the most common of NZ farmed species, are regarded as intermediate feeders, equally able to browse woody vegetation or graze grasslands, although the genus Cervidae encompasses concentrate selectors through generalist herbivores (Kay \& Staines 1981). The mouth structure of deer enables them to graze short swards and to graze selectively. Their higher metabolic rate and energy requirements for maintenance, compared to sheep, may place them at a disadvantage on short swards, and they may be more similar to cattle than sheep in their requirement for taller swards for maximum productivity. Deer have smaller mouths than sheep in relation to body mass, and smaller intake per bite (Mitchell et al. 1991). This probably explains why they graze for longer than sheep on similar swards (Colquhoun, cited by Kay \& Staines 1981), but their narrow incisor breadth gives them a comparative advantage over sheep and cattle for selection.

Studies on feral deer on the Isle of Rhum, Scotland, showed that deer grazed predominantly on areas of Agrostis/Festuca grassland which were short but of high nutritive value, and only moved out to graze the taller, but lower nutritive value heath communities in the winter, when the Agrostis greens were grazed particularly short (Charles et al. 1977; Gordon 1989a,b). Because of their smaller size, hinds were more able to meet their nutrient requirements from the Agrostis greens than were the larger stags, and remained on the high quality grazing for longer. Also, usage of high quality grass communities by deer is reduced when there is competition from sheep (Osborne 1984). Similar patterns of behaviour are apparent for the native antelope on the catena areas in the Serengeti (Jarman \& Sinclair 1979), which focus their attention on short grass communities in the wet season, only moving to taller vegetation as growth on the preferred areas declines in the dry season.

\section{Sward factors affecting selection}

As a generalisation, ruminant species of a wide range of body sizes (e.g. goats, sheep, cattle) prefer to eat a mixed diet, generally with preferential selection for legumes compared with grasses. Limited data and anecdotal evidence indicates that this is true for deer. For example, lactating red deer hinds, yearling red stags and fallow deer offered an array of forage species preferred legumes compared with grasses, and in particular, low oestrogen red clover compared with other legumes (Hunt \& Hay 1990). Preferential selection for legumes, particularly when they comprise only a low proportion in a pasture, forces animals to make a trade-off between the gains from selective grazing (i.e. a diet with higher nutrient density) and the costs of locating and selecting preferred items. This may reduce the overall rate of intake and compromise total nutrient intake. Bootsma et al. (1990) showed that young deer continuously stocked on a mixed ryegrass-white clover pasture achieved limited selection for white clover, despite the fact that clover foliage was located lower in the sward canopy than the foliage of the predominant ryegrass.

Sward characteristics affect many aspects of foraging behaviour. The principles governing the interrelationships among sward factors such as sward surface height, bulk density, leaf and stem distribution within the canopy, and animal factors, such as bite dimensions (bite area, bite depth), rate of intake (rate of biting, intake per bite), have been thoroughly described, mainly using sheep and cattle as animal models (Laca \& Demment 1996; Ungar 1996). Sward surface height, measured from the soil surface to the highest point of undisturbed leaves, usually has an overriding influence on rate of intake, and is the basis for the sward height management guidelines of $6 \mathrm{~cm}$ and $10 \mathrm{~cm}$ for maximum productivity of continuously stocked sheep and cattle, respectively (Parsons 1984; Hodgson et al. 1985). There have been comparatively few studies to identify the optimum sward surface height for deer, but there are indications that deer are affected by sward characteristics in a similar manner to sheep (Mitchell et al. 1991). In that study comparing sheep with yearling red hinds, sward height had the largest effect on bite depth, and it follows, on intake per bite, which increased with sward height in a curvilinear manner up to $20 \mathrm{~cm}$, the tallest swards tested. However, the maximum rate of intake does not necessarily translate to a maximum daily intake. This is because larger bites require more 
handling in terms of gathering and chewing, partially offsetting the advantage of large individual bites, and because animals may increase the time spent grazing to compensate for restricted rate of intake. Mitchell (1995) showed that the highest rate of intake for both sheep and deer was achieved on swards that were $10 \mathrm{~cm}$ tall because the faster rate of biting offset the smaller individual bites. The way deer trade-off rate of intake and time spent grazing is not as well understood as it is for sheep and cattle. However, the sward surface height recommended above is consistent with field studies showing maximum herbage intake and performance of deer grazing on swards of $10 \mathrm{~cm}$ (Ataja et al. 1992; Hamilton et al. 1995), a value much closer to that for cattle $(8-10 \mathrm{~cm})$ than for sheep $(4-6 \mathrm{~cm})$ (Hodgson \& Brooks 1999). This height is adequate for lactating hinds and for fast-growing weaners where a high nutrient intake is required, but a sward height of $5 \mathrm{~cm}$ is in general adequate for mature, non-lactating animals.

The ability for flexible combinations of rate of intake and time spent grazing would suggest deer may satisfy their daily nutrient intake requirements across a limited range of sward heights. While meeting the sward height guidelines described above is generally desirable for optimising intake, there are other factors that need to be taken into account when managing pastures. There may be times of the year when it is appropriate or even desirable to set different targets for sward surface height. For example, when restricting intake in order to accumulate pasture for feeding in times of deficit, or when keeping pastures shorter to maintain forage quality by preventing the accumulation of under-utilised grass, stem or dead material. Similarly, maintaining shorter swards by more frequent or intensive grazing, especially during spring, reduces the competitive effects of ryegrass against white clover and helps to keep a higher proportion of white clover present in the sward (Brock \& Hay 2001).

\section{Plant attributes affecting selection}

Diet selection implies an opportunity for choice among different food items. There are many attributes of the forage species commonly used in New Zealand that affect nutrient intake of grazing deer (Barry et al. 1999), even when they are provided as sole diets and the animal has limited opportunity to select. Outlined in this section are some of the nutrients and secondary compounds in the commonly used temperate forage grasses and legumes, which affect the nutrition of deer.

Nutritional characteristics: Forage provides fermentable substrate (soluble and structural carbohydrates, protein) for rumen microflora and microfauna. It is the by-products of this microbial digestion that supplies most of the nutrients for the animal, either by absorption directly from the rumen or following enzymatic digestion of the microbial mass in the lower digestive tract. Structural fibre (e.g. cellulose, hemicellulose) is important for maintaining effective rumen function, however its slow breakdown and clearance from the rumen may limit daily intake. Legumes (e.g. white clover, red clover) and herbs (e.g. chicory), have high concentrations of readily fermentable nutrients (soluble sugars, starch, proteins) but low concentrations of structural fibre compared with grasses. This promotes faster breakdown and clearance from the rumen (Kusmartono \& Barry 1997), allowing higher daily dry matter and nutrient intake, and deer fed these forages gain weight faster than on grasses (Freudenberger et al. 1994; Kusmartono et al. 1996).

Endophyte alkaloids: While the alternative forage species described above offer many desirable nutritional characteristics for use as specialist pasture, we still rely heavily on traditional pasture mixtures, often composed of a high proportion of perennial ryegrass. Perennial ryegrass commonly contains an endophytic fungus, which produces alkaloids that negatively affect animals grazing ryegrass dominant pastures during summer and autumn (Fletcher et al . 1999). Lolitrem B, a neurotoxin, causes ryegrass staggers, and ergovaline is a vasoconstrictor and causes heat stress. These alkaloids may also suppress dry matter intake. Production of these alkaloids tends to be greatest during summer and autumn, and grazing animals are most exposed to the effects of these alkaloids during this period. Grazing selectively for alternative species that do not contain alkaloids, such as white clover, may limit the ingestion of alkaloids, and reduce the severity of effects on animals (Cosgrove et al. 1996). However, the grass dominance typical of deergrazed pastures means that deer generally have limited scope to avoid intake of alkaloids by selecting alternative foods. A recent study, conducted with sheep, clearly demonstrated their reluctance to reduce dry matter intake as a way of avoiding ingesting alkaloids when there was limited scope for selecting alternative species (Cosgrove et al. 2002). This helps to explain the susceptibility of deer to ryegrass staggers when faced with grass-dominant pastures. Ways to alleviate the intake of alkaloids include maintaining a higher proportion of clover in pasture or providing other forages that do not contain endophytic fungi. The novel endophyte, AR1, retains the beneficial protective effects of one alkaloid, peramine, against insect predation while eliminating the toxic effects of lolitrem and ergovaline for grazing animals (Easton et al. 2001). AR1 has recently been released in a range of perennial ryegrass cultivars. These ryegrass-endophyte associations should be selected when sowing new perennial ryegrassbased pastures in most regions of New Zealand. There are exceptions to this recommendation. These include the higher rainfall areas where argentine stem weevil 
damage to ryegrass growth and persistency is not a problem (e.g. South Island West Coast), and the northem regions of the North Island where the selected endophyte AR1 does not provide the same protection against black beetle (Heteronychus arator) as does the AR6 strain (marketed as Endosafe) or the wild-type strain (Popay \& Baltus 2001).

Condensed Tannins: The condensed tannins present in some forage species improve the nutritive value by protecting plant proteins from microbial degradation in the rumen, largely to ammonia which then has to be excreted, allowing a greater flow of amino acids to the small intestine. The benefits of a higher proportion of plant protein reaching the lower digestive tract of animals feeding on forages such as birdsfoot trefoil, sulla and sainfoin, translates to improvements in many aspects of production such as liveweight gain, milk production, and wool growth (Waghorn et al. 1998). Furthermore, tannins may also alleviate the effects of gastrointestinal parasites, directly through disrupting larval growth and development within the digestive tract, or indirectly by increasing the protein supply to the lower gut of parasitised animals to offset the protein leakage caused by larval damage to the gut wall. This is a further source of benefit to animals although there is currently less evidence of their benefits for deer than for sheep or cattle. Deer grazing chicory are less affected by parasites and require fewer anthelmintic drenches (Hoskin et al. 1999). This may in part be due to the low concentration of CT in chicory, which in laboratory assays has inhibited larval viability (Schreurs et al. 2002). The presence of $\mathrm{CT}$ at moderate concentrations (e.g. 2-4\% of dry matter) may enhance preference, but at high concentrations (e.g. 6-8\%) they can deter feeding (Poli 1998) and suppress intake and absorption of amino acids (Waghorn et al. 1998). Dorycnium rectum is a browse shrub, and although it contains CT at approximately $20 \%$ of dry matter, may have potential for deer, provided it is fed with other non-CT forages (Waghorn \& Molan 2001). However, the tannincontaining plants currently available do not grow or persist well when sown as mixtures with other species especially grasses, have short growing seasons, and require intermittent grazing (e.g. rotational grazing) to ensure productivity and persistence. For these reasons they perform best when grown alone as specialist pastures, although this limits their usefulness to particular classes of animals and certain times of the year.

Oestrogens: Oestrogenic compounds present in some red clovers, lucerne and subterranean clovers can affect fertility, at least in sheep, when they form a high proportion of the diet. In addition, these compounds may deter feeding, as indicated by the strong preference deer showed for low-oestrogen red clover (Hunt \& Hay 1990).

\section{Nutritional and behavioural aspects of selection}

The strong preference that grazing ruminants have for legumes, but more importantly for a mixed diet, has implications for the way we feed animals. Conventional mixed pastures that have a low proportion of clover may constrain nutrient intake, even when criteria such as optimum sward height for maximum performance are met. Selective grazing for a preferred food item continually suppresses its proportion, while conversely one that is less preferred or avoided, ultimately dominates swards and diet. The low preference of deer for ryegrass, yet the ryegrass dominance in deer grazed swards, is evidence to support this principle. Recent studies with sheep (Cosgrove et al. 2001, 2002) and dairy cows (Marotti et al. 2001) have demonstrated the possibility for a novel management system of growing grass and clover separately instead of as an intermingled mix, and giving them the opportunity to freely choose. To our knowledge this has not been tried with deer, but providing the opportunity for them to easily combine their preference for a mixed diet and a high proportion of clover, with a high total daily intake, might benefit performance just as it does for sheep and cattle.

Providing opportunity for animals to satisfy preference by novel forage arrangements such as outlined above, are immediate, practical solutions. In the longer-term other solutions might arise from knowing the basis of their preference. A small reduction in selection for one component might relieve the competitive pressure on it and, paradoxically, result in more of that component in the sward and in the diet (Parsons et al. 1991) when nutritionally complementary food items are grown as mixtures. There may be physical and/or nutritional reasons why ruminants prefer legumes such as white clover. Sheep fed simple diets indoors select for nitrogen (crude protein), and as their need for nitrogen changes, so will selection (Kyriazakis \& Oldham 1993). White clover has a higher concentration of nitrogen than grass and this may be one reason why they prefer it. However, increasing the concentration of nitrogen in ryegrass to the same concentration as in white clover does not cause sheep to reduce their preference for clover (Cosgrove $e t$ al. 2002). Similarly, animals prefer to eat food items with high rather than low concentrations of soluble carbohydrate, but tests of the specific role of that nutrient indicate that it does not explain preference for clover. Studies such as these, and parallel studies conducted with apparent feeding deterrents (alkaloids produced by the ryegrass-endophyte association), indicate that decisions on selection or avoidance are based on a single constituent only under certain conditions (Cosgrove et 
al. 2002). Animals may prefer foods with relativel y high concentration of nitrogen or carbohydrate, and low concentration of alkaloid, but select the preferred and avoid the alternatives only when a particular nutrient or toxin is the only difference between the food items (e.g. grass with high or low $\mathrm{N}$; grass with high or nil endophyte). There are many differences between grass and clover that influence selection, and preference for clover is strongly defended against many experimentally induced variations in the grass component. The reasons why animals prefer clover are yet to be resolved.

A critical digestive adaptation of all ruminants is the ability to regurgitate and re-chew (rumination) ingested forage to enhance the breakdown of fibre, enabling them to utilise the rela tiv ely low nutrient density, fibrous feeds, typical of grassland and shrubland vegetation they naturally exploit. Associated with this is the need for a minimum level of intake of fibre to ensure effective rumen function. In the context of evolved natural behaviours, there are temporal as well as spatial aspects to diet selection. Temporal scales of selection may range from a few hours (e.g. selection of different plant parts or different species at different times of the day) to seasons within years (e.g. selection of different feeding landscapes), or even between years (O'Regain \& Schwartz 1995). Often these are associated with natural cycles in plant physiology, morphology and growth. Management systems we impose on farmed animals may reduce the need but more importantly the opportunity for expression of selective behaviours by controlling the availability and composition of forage provided. However, some aspects of selective behaviour may be constrained by the systems we impose. For example, the period of most active grazing for sheep is during the late afternoon. The diurnal peak in concentration of dry matter and soluble carbohydrate in grasses at this time of the day (Smith 1973), and the intake of fibre for subsequent rumination during the night, have been proposed as hypotheses to explain this behaviour (Newman et al. 1995). Similarly, early in the morning eating clover would be the fastest way to ingest nutrients, because clover can be eaten faster than grasses (Penning et al. 1991) because it requires less chewing, and it has a higher nutrient density (Ulyatt et al. 1988). It is not clear if deer have similar inherent patterns of selection, but such patterns are seldom observed in intensive, managed grazing systems, not because behavioural traits such as these no longer exist in highly selected farmed species, but because the management systems we use constrain their expression. Developing alternative management systems that allows expression of these behavioural traits and requirements may further improve the productivity of our grazing systems.

\section{Management and integration of forages for deer production systems}

A major limitation to the productive performance of grazing deer lies in the imbalance between seasonal variations in forage supply and demand arising as a consequence of the late spring calving season (Figure 1). This creates particular difficulties in meeting the high demands of lactating hinds during the summer, when the production and nutritive value of traditional ryegrass/ white clover pastures are limited, particularly so if the

Figure 1 Seasonal variations in pasture production and animal requirements in deer production systems in perennial ryegrass/ white clover pastures (Hodgson \& Brookes 1999).

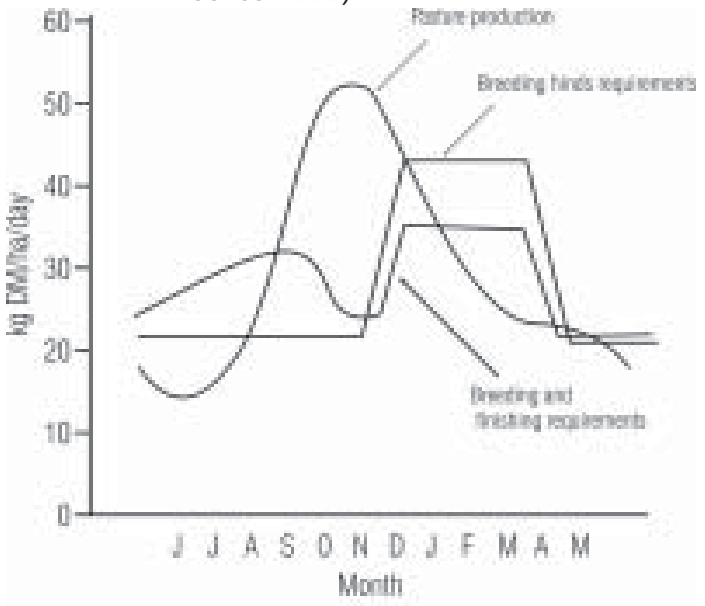

Pasture production: $11000 \mathrm{~kg}$ DW/a/day

Pessose nequirements beesing hinds (11 hinds/ha): 11000 bn $0 \mathrm{~A}$ Besedinglitishing (7 thints/ta): 11000 ig OM

Table 1 Liveweight gain of deer calves (g/day) on pastures and forage crops during lactation in summer (from Barry et al. 1999).

\begin{tabular}{lcccc}
\hline Author & Pasture & Red Clover & Chicory & Lotus corniculatus \\
\hline Niezen et al. (1993) & 333 & 433 & 385 & \\
& 331 & 410 & 404 & 485 \\
Kusmatarno et al. (1996) & 351 & & & 116 \\
Adu et al. (1997) & 399 & 127 & 122 \\
Mean relative performance & 100 & & & \\
\hline
\end{tabular}


proportion of white clover in pastures is low. A range of special purpose summer-active annual and perennial forage crops have been evaluated and their high production and high nutritive value successfully meets the needs of high producing animals at that time of the year (Niezen et al. 1993; Semiadi et al. 1993; Soetrisno et al. 1994; Kusmartono et al. 1996; Adu et al. 1997; Min et al. 1997; see Table 1). However, all of these crops have low winter production compared with perennial ryegrass-based pasture. The affect of this low winter production on the overall seasonal distribution of feed supply on the farm will depend on the type of system and when peak feed demands occur (e.g. finishing, breeding). Restricting the proportion of the total farm area sown to summer-active forages, or using winteractive forages (e.g. hybrid or annual ryegrasses) or conserved forages are two ways to maintain a balance of forage supply in winter and in summer.

\section{Conclusions}

Deer are adapted to selective browsing and grazing. Feeding systems in New Zealand rely heavily on pastures grazed in-situ, and maintaining a sward surface height of $8-10 \mathrm{~cm}$ for growing or lactating deer ensures daily intake is not limited by low availability, one of the most common restrictions to production from pasture-based systems. Of the range of forage species available for use in New Zealand pastoral systems, deer show strong preferences for legumes and herbs over grasses. Ryegrass/white clover pastures form the base of many deer feeding systems in New Zealand, and while deer are capable of grazing selectively for white clover, its proportion in pastures is generally insufficient for them to satisfy their preference and intake requirements for this high nutritive value component. In a whole-farm systems context, major constraints centre on the imbalance between the profile of annual feed requirements of deer and the seasonal distribution of pasture growth. This is the case particularly for lactating hinds, which have high requirements during late spring and summer, a time when quality and quantity of typical ryegrass-based pastures are declining, but also for growing weaners during winter when pasture growth $r$ ate is low. Deer nutrition and deer management systems can be greatly improved by the use of special purpose forages that often have the dual advantages of high nutritive value, and higher growth rates in summer than ry egrass or white clover. However, the benefit of using these special-purpose forages for providing more feed in some seasons is offset by low growth rates in other seasons. Mixed ryegrass-white clover pastures still provide a reasonable balance of production and quality throughout the year, particularly if an adequate proportion of white clover can be maintained. For the future, devising management systems that provide opportunity for animals to express their natural preferences (for example by providing preferred forages) may further improve productivity and efficiency of intensive grazing systems for deer.

\section{REFERENCES}

Adu, E.K.; Barry, T.N.;Wilson, P.R.; Kemp, P.D. 1997. Evaluation of Lotus corniculatus for increasing preweaning growth in red and hybrid deer. Journal of Agricultural Science, Cambridge 113: 197-204.

Ataja, A.M.; Wilson, P.R.; Barry, T.N.; Hodgson, J.; Hoskin, S.M.; Parker, W.J.; Purchas, R.W. 1992. Early venison production from red deer as affected by grazing perennial or annual ryegrass pastures, pasture surface height and immunisation against melatonin. Journal of Agricultural Science 118: 353-369.

Barry, T.N.; Wilson, P.R.; Kemp, P.D. 1999. A review of forage grazing systems to produce venison according to market signals. Proceedings of the New Zealand Society of Animal Production 59: 140-144.

Brock, J.L.; Hay, M.J.M. 2001. White clover performance in sown pastures: A biological/ecological perspective. Proceedings of the New Zealand Grassland Association 63: 73-83.

Bootsma, A.; Ataja, A.M.; Hodgson, J. 1990. Diet selection by young deer grazing mixed ryegrass/white clover pastures. Proceedings of the New Zealand Grassland Association 51: 187-190.

Charles, W.N.; McCowan, D.; East, K. 1977. Selection of upland swards by red deer (Cervus elaphus L.) on Rhum.Journal of Applied Ecology 14: 55-64.

Cosgrove, G.P.; Anderson, C.B. Parsons, A.J.; Brock, J.L.; Tilbrook, J.C. 2002. Can nitrogen fertilised ryegrass substitute for white clover? Proceedings of the New Zealand Grassland Association 64: 205-209.

Cosgrove, G.P.; Anderson, C.B.; Phillot, M.; Nyfler, D.; Hume, D.E.; Parsons, A.J .; Lane, G.A. 2002. The effect of endophyte alkaloids on diet selection by sheep. Proceedings of the New Zealand Society of Animal Production 62: 167-170.

Cosgrove, G.P.; Anderson, C.B.; Hyslop, M.G.; Moffat, C.A.M. 2001. Novel Grazing Management. Client Report to Meat New Zealand.

Cosgrove, G.P.; Anderson, C.B.; Berquist, T.R.N. 1996. Fungal endophyte effects on the intake, health and liveweight gain of grazing cattle. Proceedings of the New Zealand Grassland Association 57: 43-48.

Easton, H.S.; Christensen, M.J.; Eerens, J.P.; Fletcher, L.R.; Hume, D.E.; Keogh, R.G.; Lane, G.A.; Latch, G.C.M.; Pennell, C.G.L.; Popay, A.J .; Rolston, M.P.; Sutherland, B.L.; Tapper, B.A. 2001. Ryegrass endophyte: a New Zealand grassland success story. Proceedings of the New Zealand Grassland Association 63: 37-46. 
Fletcher, L.R.; Sutherland, B.L.; Fletcher, C.G. 1999. The impact of endophyte on the health and productivity of sheep grazing ryegrass-based pastures. Ryegrass endophyte: an essential New Zealand Symbiosis. Grassland Research and Practice Series No. 7: 1117.

Freudenberger, D.O.; Burns, C.J.; Toyokawa, K.; Barry, T.N. 1994. Digestion and rumen metabolism of red clover and perennial ryegrass/white clover forages by red deer. Journal of Agricultural Science, Cambridge 122: 115-120.

Gordon, I.J. 1989a. Vegetation community selection by ungulates on the Isle of Rhum. II Vegetation community selection. Journal of Applied Ecology 26: 53-64.

Gordon, I.J. 1989b. Vegetation community selection by ungulates on the Isle of Rhum. III Determinants of vegetation community selection. Journal of Applied Ecology 26: 65-79.

Hamilton, W.J.; Sibbald, A.M.; Fiest,D. 1995. The effect of sward height on the liveweight gain of farmed yearling red deer stags. Grass and Forage Science 50: 399- 404.

Hodgson, J.; Mackie, C.K.; Parker, J.W.G. 1985. Sward surface heights for efficient grazing. Grass Farmer 24: 5-10. British Grassland Society.

Hodgson, J.; Brookes, I.M. 1999. Nutrition of grazing animals. In: New Zealand Pasture and Crop Science pp. 117-132. Eds. White, J.; Hodgson, J., Oxford University Press, Auckland.

Hoskin, S.O.; Barry, T.N.; Wilson, P.R.; Charleston, W.A.G.; Hodgson, J. 1999. Effects of reducing anthelmintic input upon growth and faecal egg and larval counts in young farmed deer grazing chicory (Cichorium intybus) and perennial ryegrass (Lolium perenne)/white clover (Trifolium repens) pasture. Journal of Agricultural Science, Cambridge 132: 335345.

Hunt, W.F.; Hay, R.J.M. 1990. A photo graphic tec hnique for assessing the pasture species performance of grazing animals. Proceedings of the New Zealand Grassland Association 51: 191-196.

Jarman, P.J.; Sinclair, A.R.E. 1979. Feeding strategy and the pattern of resource partitioning in ungulates. pp. 130-163. In: Serengeti, Dynamics of an Ecosystem. Eds. Sinclair, A.R.E.; Norton-Griffiths, M.

Kay, R.N.B.; Staines, B.W. 1981. The nutrition of the red deer (Cervus elaphus). Nutrition Abstract and Reviews (B) 51: 601-622.

Kusmartono, S.A.; Barry, T.N.; Wilson, P.R.; Kemp, P.D.; Stafford, K.J. 1996. Effects of grazing chicory (Cichorium intybus) and perennial ryegrass (Lolium perenne) white clover (Trifolium repens) pasture upon the growth and voluntary feed intake of red and hybrid deer during lactation and post-weaning growth.
Journal of Agricultural Science, Cambridge. 127: 387401.

Kusmartono, S.A.; Barry, T.N. 1997. Rumen digestion and rumen outflow rate in deer fed fresh chicory (Cichorium intybus) or perennial ryegrass (Lolium perenne)/white clover (Trifolium repens). Journal of Agricultural Science, Cambridge 128: 94-97.

Kyriazakis, I.; Oldham, J.D. 1993. Diet selection in sheep: the ability of growing lambs to select a diet that meets their crude protein (nitrogen x 6.25) requirements. British Journal of Nutrition 69: 617629.

Min, B.R.; Barry, T.N.; Wilson, P.R.; Kemp, P.D. 1997. The effects of grazing chicory (Cichorium intybus) and birdsfoot trefoil (Lotus corniculatus) on venison and velvet production by weaner red and hybrid deer. New Zealand Journal of Agricultural Research. 40: 335-347.

Laca, E.A.; Demment, M.W. 1996. Foraging strategies of grazing animals. pp. 137-188. In: The ecology and management of grazing systems. Eds. Hodgson, J.; Illius, A.W. CAB International, UK.

Marotti, D.M.; Cosgrove, G.P.; Chapman, D.F.; Parsons, A.J.; Egan,A.R.; Anderson, C.B. 2001. Novel methods of forage presentation to boost nutrition and performance of grazing dairy cows. Australian Journal of Dairy Technology 56: 161.

Mitchell, R.J. 1995. The effects of sward height, bulk density and tiller structure on the ingestive behaviour of red deer and Romney sheep. PhD Thesis, Massey Univer sity.

Mitchell, R.J.; Hodgson, J.; Clark, D.A. 1991. The effect of varying leafy sward height and bulk density on the ingestive behaviour of young deer and sheep. Proceedings of the New Zealand Society of Animal Production 51: 159-165.

Newman, J.; Parsons, A.J.; Thornley, J.H.M.; Penning, P.D.; Krebs, J.A. 1995. Optimal diet selection by a generalist grazing herbivore. Functional Ecology 9: 255-268.

Niezen, J.H.; Barry, T.N.; Hodgson, J.; Ataja, A.M.; Parker, W.J.; Holmes, C.W. 1993. Growth responses in red deer calves and hinds grazing red clover, chicory and perennial ryegrass/white clover swards during lactation. Journal of Agricultural Science, Cambridge 121: 255-263.

O'Regain, P.J.; Schwartz,J. 1995. Dietary selection and foraging strategies of animals on rangeland. Coping with spatial and temporal variability. pp. 407-423. In Recent developments in the nutrition of herbivores. Proceedings of the IV ${ }^{\text {th }}$ International Symposium on the Nutrition of Herbivores. INRA Editions, Paris.

Osborne, B.C. 1984. Habitat use by red deer (Cervus elaphus L.) and hill sheep in the west Highlands. 
Journal of Applied Ecology 21: 497-506.

Parsons, A.J. 1984. Guidelines for management of continuously grazed swards. Grass Farmer 17: 5-9. British Grassland Society.

Parsons, A.J.; Harvey, A.; Johnson, I.R. 1991. Plantanimal interactions in a continuously grazed mixture. II. The role of differences in the physiology of plant growth and of selective grazing on the performance and stability of species in a mixture. Journal of Applied Ecology 28: 635-658.

Penning, P.D.; Rook, A.J.; Orr. 1991. Patterns of ingestive behaviour of sheep continuously stocked on monocultures of ryegrass or white clover. Applied Animal Behaviour Science 31: 237-250.

Poli, C.H.E.C. 1998. Effects of physical and biochemical characteristics of contrasting legume swards on selective behaviour of grazing cattle. PhD Thesis, College of Sciences, Massey Uni versity, Palmerston North.

Popay, A.J.; Baltus, J.G. 2001. Black beetle damage to perennial ryegrass infected with AR1 endophyte. Proceedings of the New Zealand Grassland Association 63: 267-271.

Schreurs, N.M.; Molan, A.L.; Lopez-Villalobos, N.; Barry, T.N.; McNabb, W.C. 2002. Effect of grazing undrenched weaner deer on chicory or perennial ryegrass/white clover pasture on gastrointestinal nematode and lungworm viability. Proceedings of the New Zealand Society of Animal Production 62: 143144.

Semiadi, G.; Barry, T.N.; Wilson, P.R.; Hodgson, J.; Purchas, R.W. 1993. Growth and venison production from red deer (Cervus elaphus) grazing red clover (Trifolium pratense) or perennial ryegrass (Lolium perenne) white clover (Trifolium repens) pasture. Journal of Agricultural Science, Cambridge. 121: 265271.

Smith, D. 1973. The non-structural carbohydrates. pp. 106-151. In: The chemistry and biochemistry of herbage. Eds. Butler, G.W. Bailey, R.W. Academic Press, London.

Soetrisno, E.; Barry, T.N.; Wilson, R.P.; Hodgson, J .; Purchas, R.W. 1994. Effects of grazing red clover (Trifolium pratense) or perennial ryegrass (Lolium perenne) white clover (Trifolium repens) pastures upon growth and venison production from weaner red deer (Cervus elaphus). New Zealand Journal of Agricultural Research 37: 19-27.

Ulyatt, M.J.; Thomson, D.J.; Beever, D.E.; Evans, R.T.; Haines, M.J. 1988. The digestion of perennial ryegrass (Lolium perenne $\mathrm{L}$ cv. Melle) and white clover (Trifolium repens L cv. Blanca) by grazing cattle. British Journal of Nutrition 60. 137-149.

Ungar, E.D. 1996. Ingestive behaviour. pp. 186-218. In: The ecology and management of grazing systems. Eds. Hodgson, J.; Illius, A.W. CAB Intemational, UK.

Waghorn, G.C.; Douglas, G.B .; Niezen, J.H.; McNabb, W.C.; Foote, A.G. 1998. Forages with condensed tannins - their management and nutritive value for ruminants. Proceedings of the New Zealand Grassland Association 60. 89-98.

Waghorn, G.C.; Molan, A.L. 2001. Effect of condensed tannins in Dorycnium rectum on its nutritive value and on the development of sheep parasite larvae. Proceedings of the New Zealand Grassland Association 63: 273-277. 